\title{
Effects of Strengthening Options in Improving the Lateral Responses of RC Frame Building
}

\author{
Darpan B. Doshi ${ }^{1}$, J A. Amin ${ }^{2}$ \\ ${ }^{1}$ Structural Engineer, Ashirvad Consultant, Vadodara, India, \\ ${ }^{2}$ Sardar Vallabhbhai Patel Institute of Technology, Vasad-388306, India, \\ Email: doshidarpan8@gmail.com,jamin_svit@yahoo.com
}

\begin{abstract}
During recent past, it was observed that a large number of existing RC frame buildings with irregularities have poor performance or even collapsed during a strong earthquake. Therefore, strengthening of these types of buildings is required because of its inherent irregularities and low resistance against lateral forces. In the present study, efforts were made to investigate and critically assess the effectiveness of some strengthening options in enhancing the seismic performance of typical four storey asymmetric RC frame building using nonlinear static analysis. The different strengthening options studied were infilled RC frames, design of soft storey RC beams and columns by 2.5 times higher design forces as per IS 1893(part 1), design of only soft storey columns by 2.5 times higher design forces, provision of bracing at open ground storey and provision of lateral buttresses in open ground storey. The effect of these strengthening options in improving the ductility as well as lateral strength of asymmetric RC frame building for enhancing seismic behaviour was also studied. The strengthening option suggested by IS: 1893, designing the beams and columns of soft-story for higher forces was found to increase the lateral strength of the RC building 2.29 times as compared to bare $\mathrm{RC}$ frame building but it observed ineffective in improving the lateral deformability/ductility of RC frame building. Yield and ultimate lateral strength of the RC frame building with diagonal braces in all bays was found to be the highest, which is 4.31 and 7.12 times higher than the bare RC frame building among all other strengthening option, indicating the most effective strengthening option.
\end{abstract}

Keywords: RC frame; ductility; pushover analysis; lateral strength

\section{Introduction}

Existing reinforced concrete buildings having a vertical irregularities like open ground storeys designed by the earlier version seismic standard of India IS 1893-1984 [1], applicable till it's revision in 2002 [2], represent a structural configuration that has suffered considerable damage and even collapsed during strong earth-quake in India during the past few years (e.g. Bhuj 2001 earthquakes, Nepal 2015 earthquakes etc). During the past earthquakes, it was also observed that open ground storey columns of buildings either suffered severe damages or failed completely, thereby causing the damage of the building. When an individual storey in a building, often the ground level storey is made taller and/or more open in construction by omitting the exterior/interior walls for parking lots, thus causing an abrupt change in stiffness at that level, is called a soft storey. As per IS: 1893, such a storey with a lateral stiffness less than $70 \%$ of the average stiffness of the three stories above is called soft storey. Torque is also induced in an asymmetric structure due to eccentricity between center of mass and centre of stiffness. The response of such irregular buildings to earthquake actions is characterized by substantial uncertainty, while their overall behavior is strongly influenced by the response of their open ground stories. Present building codes for design of RC structures like IS 1893- 2002 of India [2], Euro code 8 (EC8, 2004) [3] and IBC 2003 [4] include special provisions for buildings with vertical irregularities, one of which is the open ground story. According to the guidelines of these codes, RC members of open/soft storey require to be designed for higher design seismic forces obtained by multiplying the internal forces by a factor given in codes, which are in the range of 2.0 to 3.0 in order to prevent formation of a plastic side sway story mechanism. As an example, IS 1893 (Part-1): 2002 for an 
earthquake resistant design of RC structures recommends the design of the beams and columns of the soft stories by increasing their internal design seismic forces 2.5 times.

The sudden reduction/change in stiffness and strength due to the absence of brick infill walls at open ground storey level is a serious structural problem. Unfortunately, this problem was not acknowledged by earlier edition of codes and this, coupled with other deficiencies and poor construction practices in the past, led to weaker than expected buildings, as observed by their performance during past earthquakes (Antonopoulos and Anagnostopoulos, 2010 [5], Jain et al. 2002 [6]; Dolsek and Fajfar 2001[7]). The advantages of providing masonry infills and bracings in RC structures are well recognized (Tamboli and Amin; 2015 [8]). Past researchers had recommended several strengthening options for open ground storey buildings like, increasing stiffness and lateral strength of ground-story members, capacity design, providing diagonal bracings, providing shear wall and providing lateral buttresses in the ground story (Kaushik et al. 2009 [9]; Das and Nau 2003 [10]; Fardis et al. 1999 [11]; Selvakoodalingam et al. 1999 [12], Negro and Colombo, 1997 [13]).

The work reported in this paper addresses the assessment of some strengthening options for the most vulnerable class of existing RC frame buildings, namely asymmetric buildings with an open ground story designed and built using conventional method of design. The present paper examined the feasibility and effectiveness of some strengthening options of 4-storey asymmetric RC frame buildings, aiming at improving the lateral strength and reducing their vulnerability due to their irregularity and weak ground story. In this study, pushover analysis of typical 3-D Reinforced concrete frame buildings was carried out using SAP 2000 [14].

\section{Details of Considered Frame}

In this study, a four-storey asymmetric RC frame building shown in fig. 1 was analyzed and designed considering all the possible load combination according to Indian code of practice IS 456-2000 [15] and IS 1893-2002 (Part 1), using a linear elastic analysis. The considered RC building was designed using the common design practice neglecting strength and stiffness of masonry infill walls in analysis and design procedure. The building consists of an assembly of cast in place reinforced concrete beams, columns and slab at floor level was modeled as rigid diaphragm. The building had a static eccentricity of $0.55 \mathrm{~m}$ in $\mathrm{X}$ and Y-direction. Columns were assumed to be fixed at their bases. Height of ground storey had been kept $4.2 \mathrm{~m}$ and height of remaining storeys had been set to $3.2 \mathrm{~m}$. Grades of concrete and reinforcing steel assumed were M25 and Fe415 respectively. Live load has been assumed as $3.0 \mathrm{kN} / \mathrm{m}^{2}$ at all storey levels and $25 \%$ of live loads except at roof level were considered for seismic weight and seismic forces calculation. It was assumed that the building consisted of $230 \mathrm{~mm}$ thick brick masonry infills. Thickness of floor/slabs was taken as $125 \mathrm{~mm}$. Building was assumed to be located in zone-IV (zone factor $=0.24$ ) of IS: 1893 and supported on medium soil. Size and reinforcement details of designed beams and columns are shown in Table 1 and 2. The considered building has a fundamental natural time period of 0.31 and 0.29 second in $\mathrm{X}$ and $\mathrm{Y}$-direction respectively. The evaluated design seismic base shear and corresponding lateral forces at storey level of the considered building as per IS 1893 Part 1, are shown in Table 3.

Table 1. Size and reinforcement details of beams

\begin{tabular}{l|l|l|l|l}
\hline \multicolumn{1}{c|}{ Storey level } & Size $(\mathrm{mm})$ & Top reinforcement & Bottom reinforcement & Stirrups \\
\hline Ground & $300 \times 550$ & 4 nos. of $20 \mathrm{~mm}$ dia & 4 nos. of $20 \mathrm{~mm}$ dia & 8 dia at $90 \mathrm{~mm}$ \\
\hline First & $300 \times 550$ & 4 nos. of $18 \mathrm{~mm}$ dia & 4 nos. of $18 \mathrm{~mm}$ dia & 8 dia at $90 \mathrm{~mm}$ \\
\hline Second & $300 \times 550$ & 4 nos. of $16 \mathrm{~mm}$ dia & 4 nos. of $16 \mathrm{~mm}$ dia & 8 dia at $90 \mathrm{~mm}$ \\
\hline Roof/third storey & $300 \times 550$ & 4 nos. of $12 \mathrm{~mm}$ dia & 4 nos. of $12 \mathrm{~mm}$ dia & 8 dia at $90 \mathrm{~mm}$ \\
\hline
\end{tabular}

Table 2. Size and reinforcement details of columns

\begin{tabular}{l|l|l|l}
\hline Storey level & Size $(\mathrm{mm} \times \mathrm{mm})$ & Longitudinal reinforcement & Lateral ties \\
\hline Ground storey & $375 \times 375$ & 8 nos. of $16 \mathrm{~mm} \mathrm{dia}$ & 12 dia at $75 \mathrm{~mm}$ \\
\hline
\end{tabular}




\begin{tabular}{l|l|l|l}
\hline First storey & $375 \times 375$ & 6 nos. of $16 \mathrm{~mm}$ dia & 12 dia at $75 \mathrm{~mm}$ \\
\hline Second storey & $375 \times 375$ & 4 nos. of $16 \mathrm{~mm}$ dia & 12 dia at $75 \mathrm{~mm}$ \\
\hline Roof/Third storey & $375 \times 375$ & 4 nos. of $12 \mathrm{~mm}$ dia & 12 dia at $75 \mathrm{~mm}$ \\
\hline
\end{tabular}

Table 3. Seismic weight and lateral forces at storey level

\begin{tabular}{l|l|l|l|l|l}
\hline Storey level & $\mathrm{w}_{\mathrm{i}}(\mathrm{kN})$ & $\mathrm{h}_{\mathrm{i}}(\mathrm{m})$ & $\mathrm{w}_{\mathrm{i}} \mathrm{h}_{\mathrm{i}}{ }^{2}$ & $\mathrm{Q}_{\mathrm{i}}=\mathrm{Vb}\left[\mathrm{w}_{\mathrm{i}} \mathrm{h}_{\mathrm{i}}{ }^{2} / \sum \mathrm{w}_{\mathrm{i}} \mathrm{h}_{\mathrm{i}}{ }^{2}\right]$ & $\mathrm{V}(\mathrm{kN})$ \\
\hline Roof/Third storey & 2637 & 13.8 & 502190.3 & 347 & 44 \\
\hline Second storey & 3292 & 10.6 & 369889.1 & 256 & 169 \\
\hline First storey & 3292 & 7.4 & 180269.9 & 125 & 425 \\
\hline Ground storey & 3642 & 4.2 & 64244.9 & 44 & 772 \\
\hline$\Sigma$ & 12863 & & 1116594 & $\mathrm{~V}_{\mathrm{b}}=772$ & \\
\hline
\end{tabular}

$\mathrm{V}_{\mathrm{b}}=\mathrm{Z} / 2^{*} \mathrm{I} / \mathrm{R} * \mathrm{Sa} / \mathrm{g}=772 \mathrm{kN}$, where $\mathrm{Z}=$ zone factor, $\mathrm{I}=$ importance factor, $\mathrm{R}=$ response reduction factor, $\mathrm{Sa} / \mathrm{g}=$ horizontal spectrum acceleration for $5 \%$ damping.

\section{Modeling and Nonlinear Static Pushover Analysis of RC Frame Building}

A three-dimensional mathematical model of the physical structure will be used that represents the spatial distribution of the mass and stiffness of the structure to an extent that is adequate for the calculation of the significant features of the considered RC frame building's response The diaphragm action due to slab was considered by assigning a diaphragm to all nodes at each floor level. Damping ratio of 5 percent is assumed. SAP analysis software was used to perform the nonlinear static pushover analysis of considered RC frame building. Plasticity was assumed to be lumped at the potential locations of failures in $\mathrm{RC}$ members to take into account the material nonlinearity in various members of considered RC buildings. A coupled axial force and biaxial bending moment hinge (P-M2-M3 hinge) and M3 hinge were assigned at both ends of each column and beam respectively, where the resultant bending moments under lateral and vertical loadings are maximum. For a beam, since the shear is maximum at the ends of beam, shear hinges were assigned at both ends of the beam. For a column, since the shear is constant throughout the height, one shear hinge was assigned at the mid height to distinguish it from as flexure hinge. The idealized force-deformation curve and acceptance criteria for various performance levels in beams and columns have been considered as per FEMA 356 [16] guidelines. The non-linear load-deformation relation adopted from FEMA 356 for the push over analysis is shown in fig. 2. The generalized load-deformation relation shown in Figure 3(a) shall be described by linear response from A (unloaded component) to an effective yield $\mathrm{B}$, then a linear response at reduced stiffness from point $\mathrm{B}$ to $\mathrm{C}$, then sudden reduction in lateral load resistance to point $\mathrm{D}$, then response at reduced resistance to $\mathrm{E}$, and final loss of resistance thereafter. The slope from point $\mathrm{B}$ to $\mathrm{C}$, ignoring effects of gravity loads acting through lateral displacements, shall be taken as 0 to $10 \%$ of the initial slope unless an alternate slope is justified by experiment or analysis. Point $\mathrm{C}$ shall have an ordinate equal to the strength of the component and an abscissa equal to the deformation at which significant strength degradation begins. Line DE represents the residual strength of the member. The equivalent lateral force distribution adopted for this pushover analysis was as suggested in IS 1893:

$$
Q_{i}=V_{b} \times \frac{W_{i} H_{i}^{2}}{\sum_{j=1}^{n} W_{i} H_{i}^{2}}
$$

where $Q_{i}$ is the equivalent lateral force on the ith floor, $V_{b}$ is the design base shear, $W_{i}$ the seismic weight of the ith floor, $h_{i}$ the height up to the ith floor, and $n$ is the total number of storeys. In NSPA, the design gravity loads were applied before applying the incremental lateral forces. The gravity loads on beams were applied as distributed element loads based one way or two way distribution. First, a static analysis was performed for the full gravity load in a single step. The state of the structure from this analysis was saved and subsequently the static pushover analysis was conducted starting from this state of the structure. For the nonlinear static analysis, both the load control and the displacement 
control strategies were adopted. The analysis was load controlled up to the first yield and displacement controlled thereafter. The inclusion of $\mathrm{P}-\Delta$ effects changes the lateral force-deformation behavior of a frame. The output of a nonlinear static analysis is generally presented in the form of a 'pushover curve', which is typically the base shear $\mathrm{v} / \mathrm{s}$ roof displacement plot. The plastic rotations for individual components were checked at every load/displacement increment against the respective performance limit limits based on the induced load levels. The performance level was marked on the pushover curve, when for the first time any of these limits was reached, either indicating the formation of plastic hinge in a member or failure of a member.

The masonry infills walls were modeled according to diagonal compressive struts approach along the loaded diagonals. The width of the diagonal strut and off diagonal struts was taken as one-eighth and one-sixteenth of the diagonal length of the wall respectively. The thickness of struts was taken equal to the thickness of walls, i.e., $230 \mathrm{~mm}$. The off-diagonal struts were connected to the columns at a distance of $\alpha \mathrm{m} / 2$ from the junction of beam-column. (Pauly and Priestly, 1992 [17], Stafford-smith and Carter, $1969[18])$.

$$
\alpha_{m}=\frac{\pi}{2} \sqrt[4]{\frac{4 E_{C} I_{c} h_{m}}{E_{m} t \sin (2 \theta)}}
$$

where $E_{c}$ and $I_{c}$ are elastic modulus of concrete in column and M.I. of column section respectively, $h_{m}$ is height of masonry, $\mathrm{t}$ is thickness of masonry, $\theta$ is angle of inclination of diagonal strut with horizontal. Axial Plastic hinges ( $\mathrm{P}$ hinge) were assigned at the middle of the equivalent struts. Compressive stressstrain curve for masonry obtained experimentally by Kaushik et al. (2009) had been used to assign the axial hinge properties to the diagonal struts.

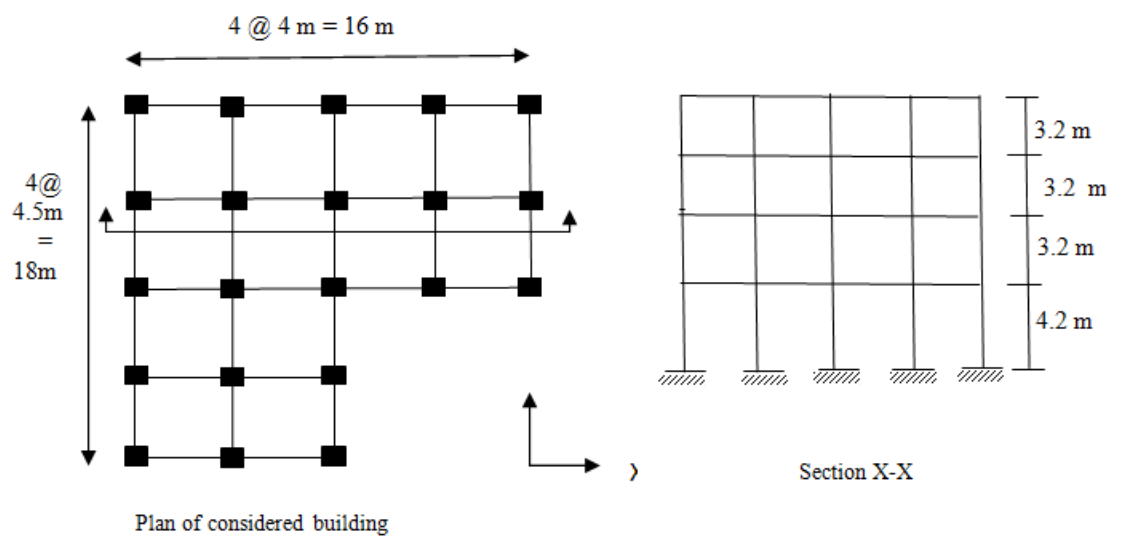

Figure 1. Plan of asymmetric RC frame building

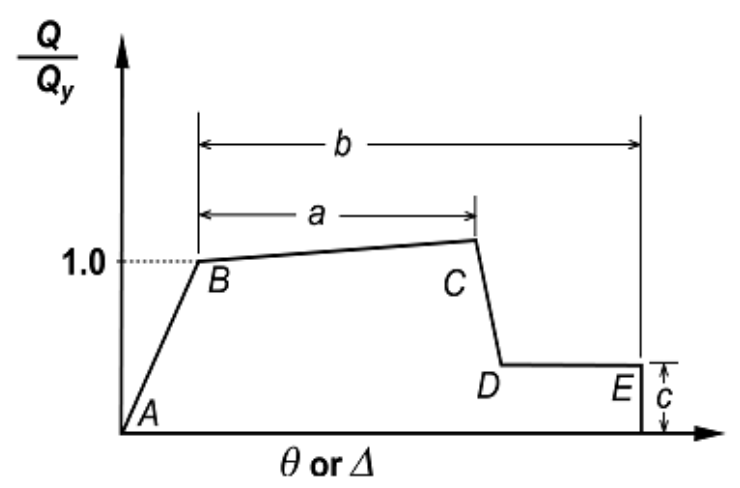

Figure 2. Generalized force-deformation curve for frame elements 


\section{$4 \quad$ Strengthening Options Studied}

Nonlinear static pushover analyses of considered four stored asymmetric RC frame building were performed by considering following cases.

1. Bare frame (BF) building,

2. Open ground storey RC frame building,

3. Fully infilled RC frame building,

4. Open ground storey RC members designed using method specified by IS 1893:2002,

5. Open ground storey columns only designed using higher design forces,

6. Provision of bracings in an open ground storey,

7. Provision of lateral buttresses in an open ground storey.

\section{$5 \quad$ Results and Discussions}

Nonlinear static pushover analysis of typical 3-D Reinforced concrete frame building strengthened using different options was carried out using SAP 2000 analytical software to obtain the capacity/pushover curve. The equivalent lateral load at each storey level obtained using IS: 1893 (Part-1):2000 had been used as lateral loading pattern for carrying out the nonlinear pushover analysis. The lateral displacement at a nodal point close to centre of the mass of top floor and corresponding base shear has been recorded to obtain the pushover curve. Capacity/pushover curves obtained from the pushover analysis are shown in Figs. 3 to 11. The pushover curves were approximated in the form of multi-linear idealized diagram to indicate the various important nonlinear events/stages. From the idealizes capacity curve the yield lateral strength, ultimate lateral strength and the ductility of the RC frame building strengthened using the different options were also evaluated.

The following stages have been observed during the pushover analysis to describe the nonlinear behavior of RC frame member: (1) PC1: formation of plastic hinge in the column at ground-storey; (2) PB1: formation of plastic hinges in ground-storey beams; (3) PCB2: formation of plastic hinges in beams and columns of higher stories; (4) PW1: formation of plastic hinges in diagonal struts (infills) at the ground storey; (5) PW2: formation of plastic hinges in struts/infills in upper storey; (6) FC1: failure of ground-storey column; (7) FB1: failure of the ground-storey beams; (8) FCB2: failure of the column and/or beams in upper stories; (9) FW1: failure of the ground-storey infills; and (10) FW2: failure of infills in upper stories; (11) PBU: formation of plastic hinge in lateral buttresses; (12) PBr: formation of plastic hinge in the ground-storey bracing; (13) FBU: failure of lateral buttresses.

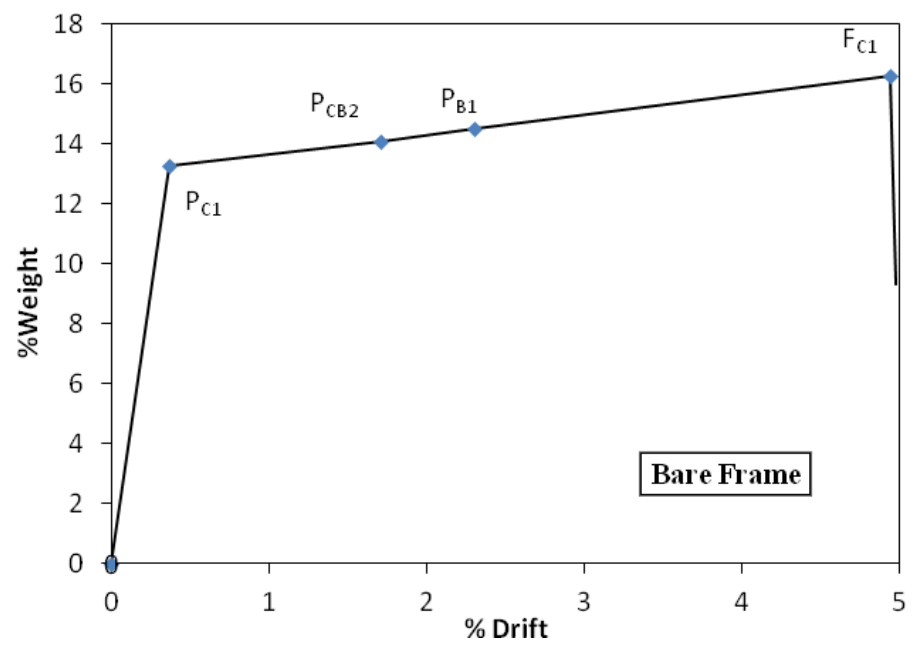

Figure 3. Pushover curve for bare frame 


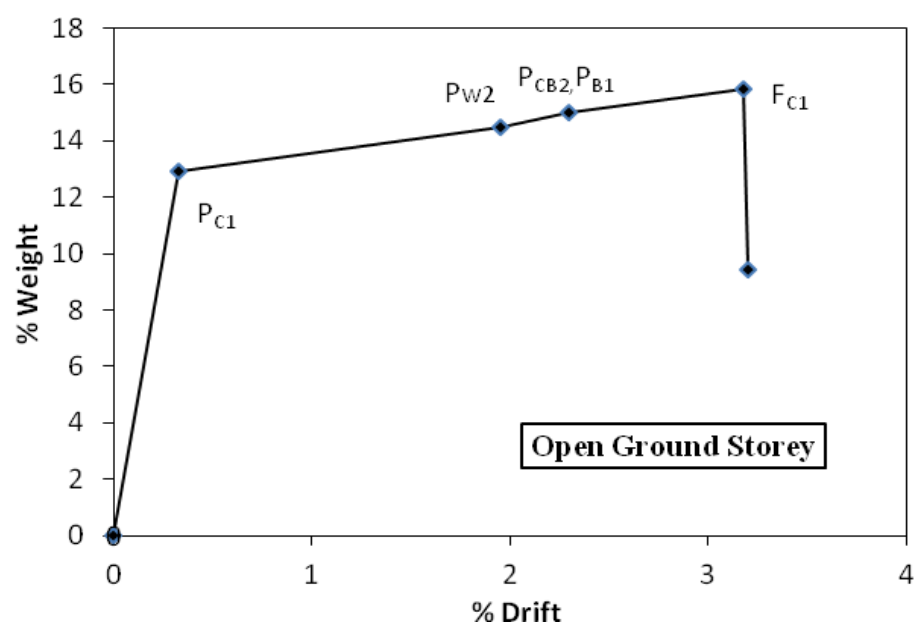

Figure 4. Pushover curve for open first storey frame

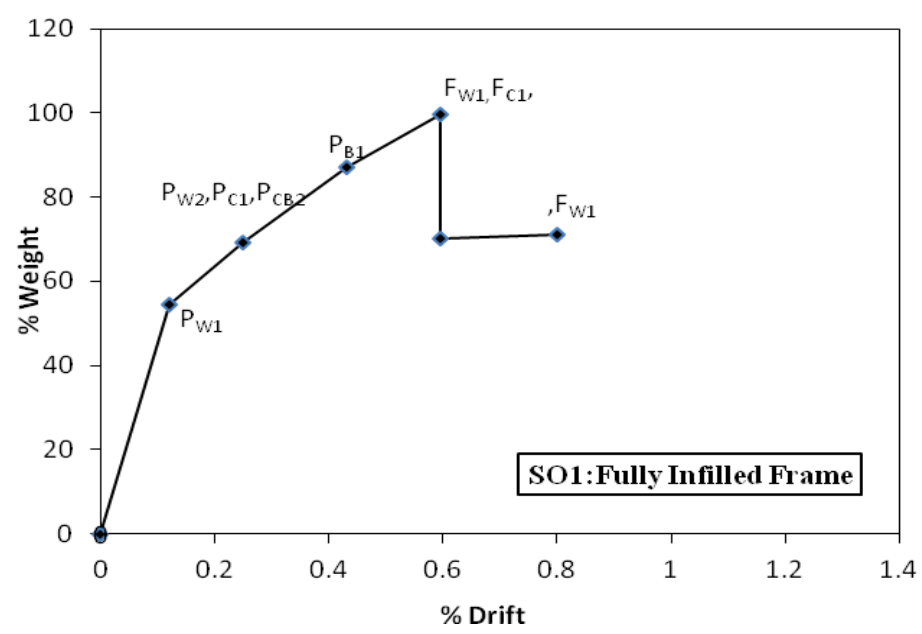

Figure 5. Pushover curve for fully infill frame (SO1)
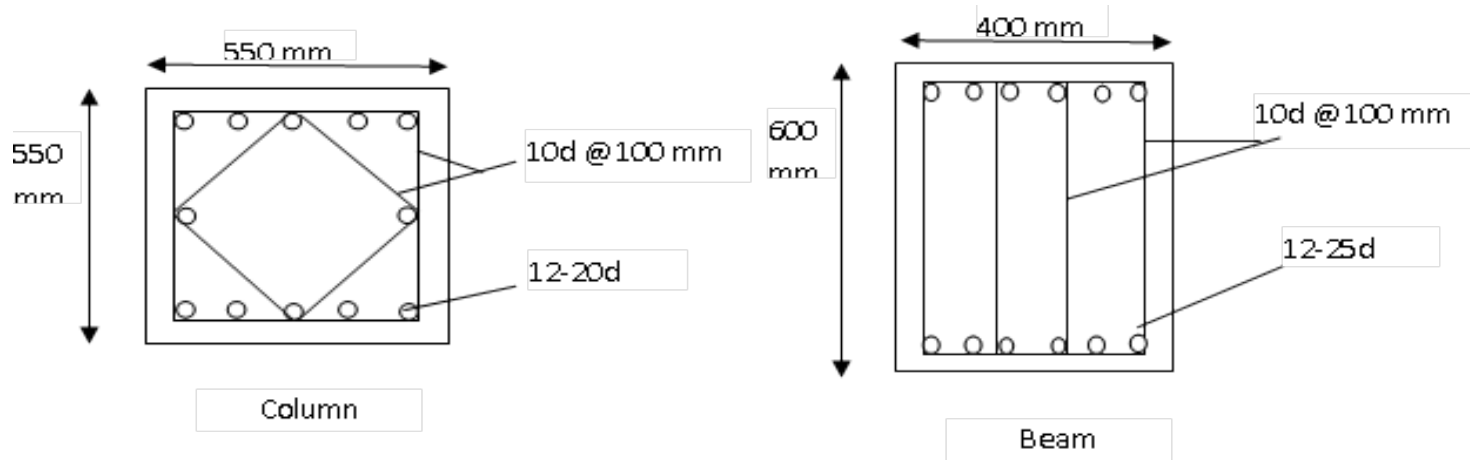

Figure 6. Details of modified beam and column as per code (IS 1893) specified method 


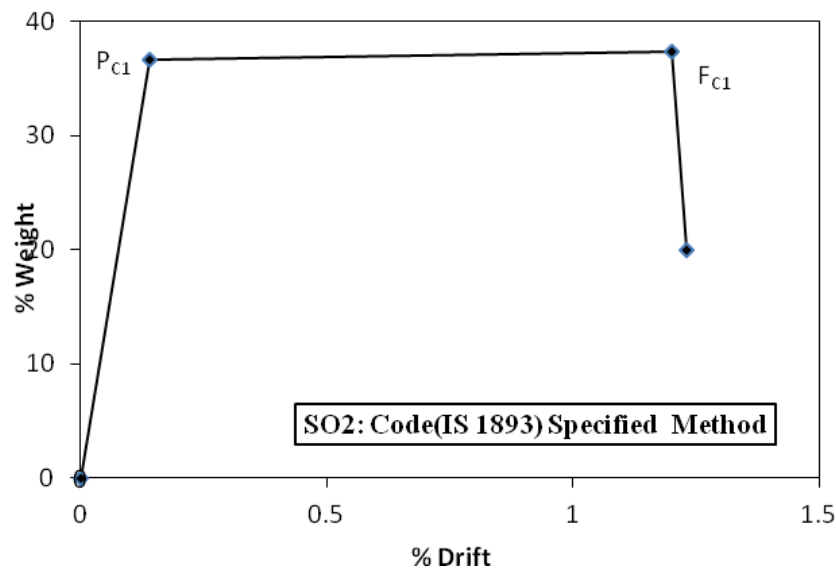

Figure 7. Pushover curve for code specified method (SO2)

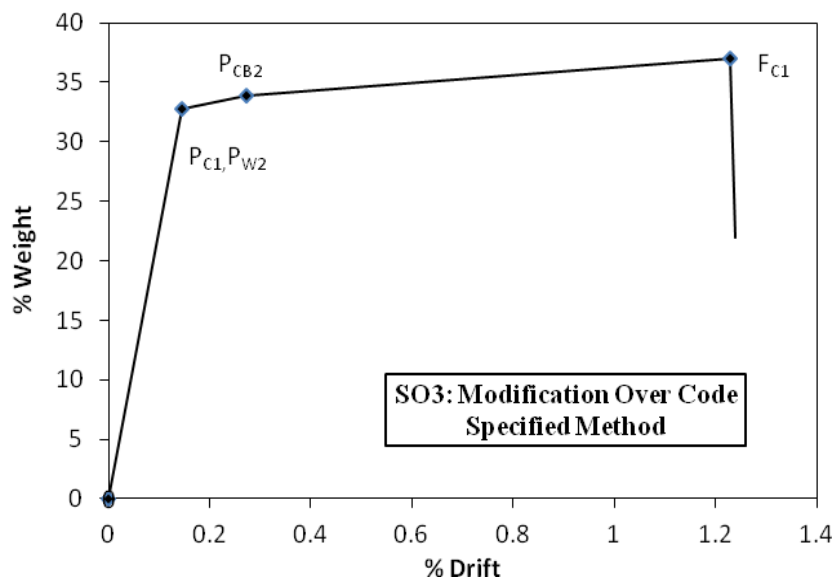

Figure 8. Pushover curve for modified code specified method (SO3)

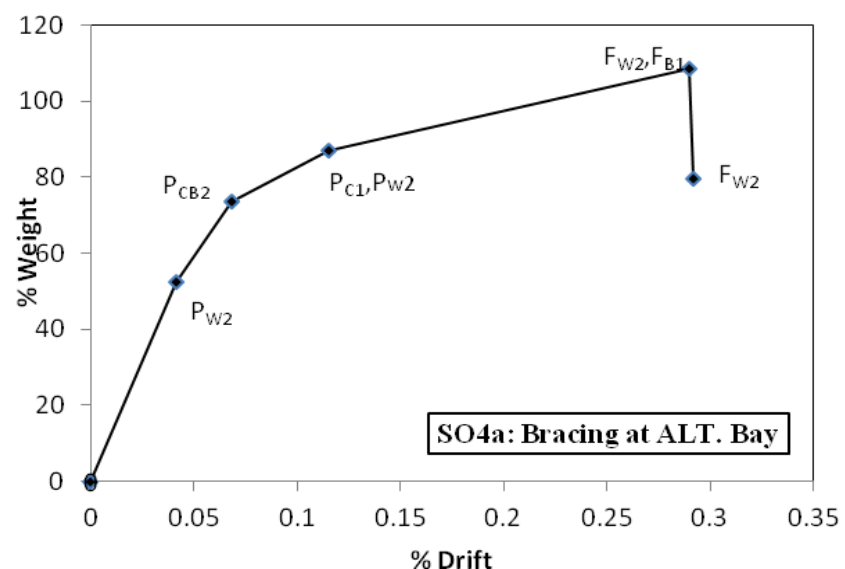

Figure 9. Pushover curve for bracing at alt. bay (SO4a) 


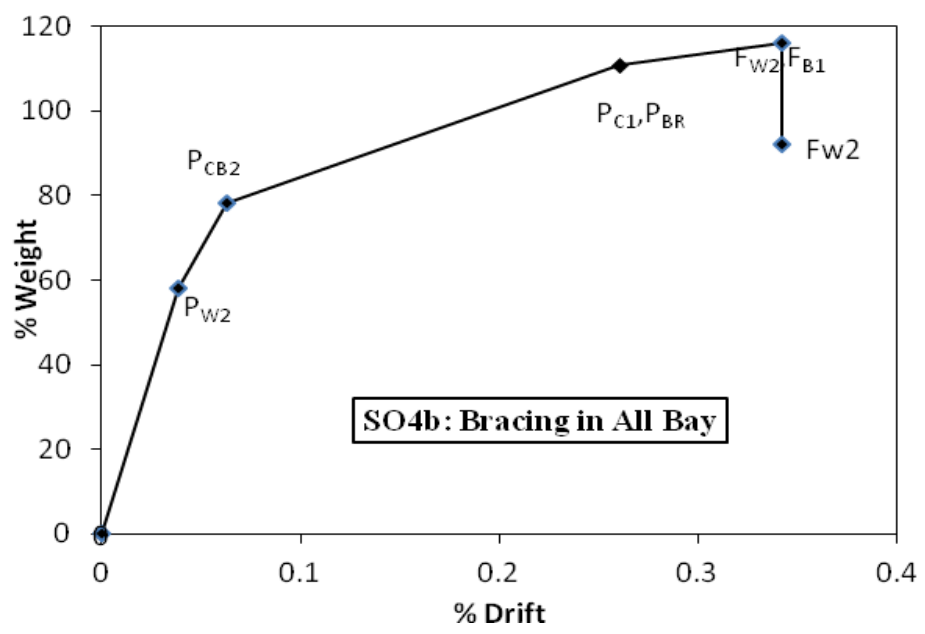

Figure 10. Pushover curve for bracing at all bay (SO4b)

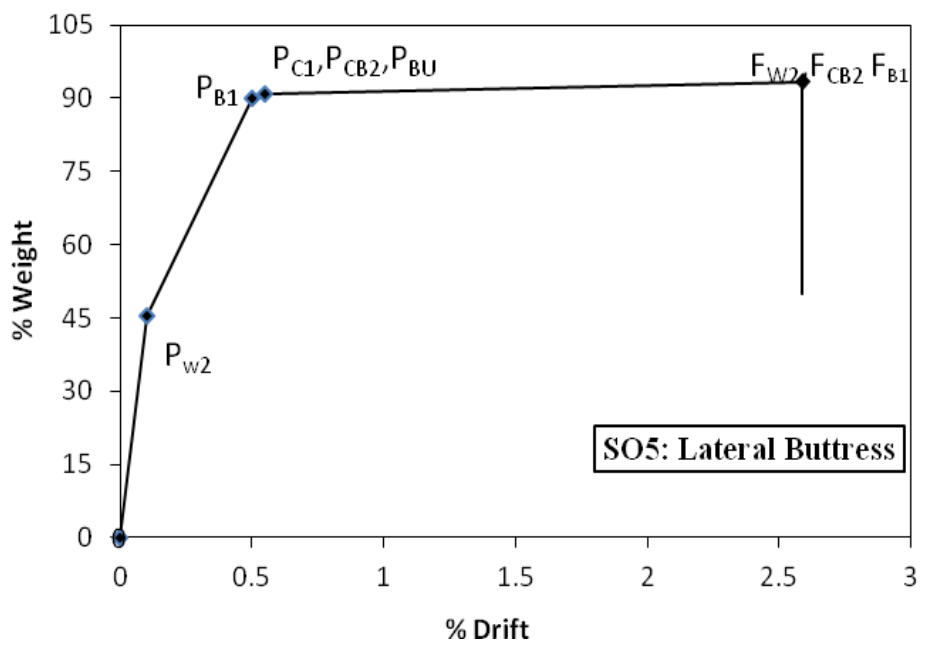

Figure 11. Pushover curve for provision of lateral buttresses (SO5)

\subsection{Bare RC Frame Building}

The stiffness/strength of brick masonry infills were ignored during the analysis and design process of bare frame buildings. Fig. 3 shows the pushover curve of the bare RC frame building. Various members of bare RC frame building behaved linearly up to roof displacement of $0.36 \%$ drifts and corresponding seismic base shear of about $13.28 \%$ of seismic weight. The well scattered plastic hinges have been observed in various structural members along the height of the building. The considered RC building collapsed at the lateral drift of $4.94 \%$ and ultimate base shear corresponding to $16.27 \%$ of seismic weight. Failure of the frame took place due to the flexure failure of open ground storey columns at lateral drift of $4.94 \%$, indicating its ductile behavior. Failure of bare RC frame/building took place due to the failure of the ground-storey columns because the bare frame/building was analyzed and designed as a weak column-strong beam frame system to reflect the common design practice adopted by structural engineers of many countries including India. 


\subsection{Open Ground Storey RC Frame Building}

In this case, the ground storey was kept open and having masonary infills at all other stories. The strength and stiffness of masonry infills were considered at the upper stories using three diagonal strut approach in the pushover analysis. The capacity curve for open ground storey RC frame building is shown in Fig. 4. Linear behavior of the frame was observed up to lateral drift of $0.325 \%$ and base shear corresponding to $12.91 \%$ of seismic weight. The failure of the frame took place due to the flexure and shear failure of open ground storey columns and beams. The failure of the frame was observed at lateral drift of $3.18 \%$ and base shear corresponding to $15.85 \%$ of seismic weight. Lateral yield and ultimate strength of this type of frame building was reduced by approximately $3 \%$ as compared to that of bare $\mathrm{RC}$ frame building. Most of the hinges and lateral deformation were found to be concentrated at soft ground storey columns due to the presence of heavy mass on subsequent upper stories caused by the presence of masonary infills and substantial lower stiffness of ground storey columns as compared to upper storey columns due to absent of infills at ground storey along with larger height of ground storey column. As a result, force demand on ground storey columns and beams became very high with increasing lateral deformation. Displacement ductility of open ground storey building was observed to be approximately $28 \%$ less than that of bare frame building.

\subsection{Strengthening Option 1 (SO1): Fully Infilled Frame}

In this case, strength and stiffness of masonry infill was considered at all stories. As a result, large increase in lateral strength and stiffness of the frame was observed. Generally infill walls in RC frame buildings act as a main energy dissipating mechanism, when it is subjected to the time varying forces. These types of frames are used to provide lateral resistance in region of high seismicity, especially in those places where masonry is still a conventional material due to economical and traditional reasons. The capacity curve for fully infilled RC frame building is shown in Fig.5. First, inelastic activity was observed at lateral drifts of only $0.12 \%$ and at very high lateral load corresponding to $54.15 \%$ of seismic weight, indicating very stiff and strong system. Failure of some of the masonry infills at ground storey took place at $0.6 \%$ of lateral drift and the base shear corresponding to $99.73 \%$ of seismic weight. This indicates the brittleness of the fully infill frame system. Displacement ductility of fully infilled RC frame building was observed to be approximately $62 \%$ lower than that of bare RC frame building. Yield strength and ultimate strength of fully unfilled RC frame building was found to be 4.08 and 6.13 times more than that of bare RC frame building respectively. After the failure of the some of the groundstorey infills, substantial reduction in the lateral strength of this type of RC frame building was observed. It is worth to note that the presences of infill walls at ground storey prevent early failure of ground storey columns. Yield and ultimate strength of fully infilled frame building was found to be 4.19 and 6.29 times more than that of open ground storey RC frame building respectively.

\subsection{Strengthening Option 2 (SO2): IS 1893-2002 Code-Specified Method}

IS 1893, (Part-1) -2002, for earthquake resistant design of structures recommends an increase in the strength of the soft stories columns and beams, by magnifying their respective internal seismic forces by 2.5 times. Whereas Eurocode 8 recommends an increase in the resistance of the soft stories columns, by magnifying their internal forces due to seismic actions by a factor of 1.50 to 4.68 depending upon some other structural factors. Israeli seismic code SII 1995 [19] suggests that members of open storey as well as members of one adjacent storey above are to be designed for higher forces of 2.1 to 3.0 times the actual seismic forces.

In this strengthening option the open ground storey members are designed for 2.5 times the design seismic forces as per IS 1893:2002 guidelines. Reinforcement details of modified soft storey beams and columns are shown in Fig. 6. Elastic behavior was observed up to $0.14 \%$ drifts and up to base shear corresponding to $36.67 \%$ of seismic weight as shown in fig.7. The ultimate lateral strength of building was found to be $37.32 \%$ of seismic weight and corresponding drift was about $1.2 \%$. Plastic hinges were observed to be concentrated at only open ground storey columns because of their increased stiffness, whereas plastic hinges were not found at ground storey beams. The failure of the building frame took place due to the flexure failure of ground storey columns. Therefore it is required to determine the 
advantage of increasing the design forces of open ground storey beams. Yield lateral strength and ultimate strength of this type of building (SO2) was found to be 2.76 and 2.29 times more than that of bare RC frame building respectively. Whereas yield and ultimate strength of this type of frame building (SO2) was found to be 2.84 and 2.35 times more than that of open ground storey RC frame building respectively. Displacement ductility of this type of frame building was observed to be approximately $37 \%$ lower than that of bare RC frame building.

\subsection{Strengthening Option 3 (SO3): Modification over Code-Specified Method}

Push over curve of considered RC frame building strengthen according to IS 1893 specified method (SO2) shows that plastic hinges were formed only at ground storey columns and not at ground storey beams. Therefore, additional force demands on the open ground-story columns (whose strengths were increased by 2.5 times) may exert, due to the increase in the strength of ground-story beams. Fardis and Panagiotakos (1997) studied the similar clauses of earlier version of Eurocode- 8 for buildings with severe vertical irregularities and proved the similar facts. The latest version of Eurocode 8 (CEN 2004) suggests the increase in the lateral strength of only soft-story columns. Therefore in line with Eurocode 8 , in strengthening option 3 only columns of the ground/soft story were designed by increasing the internal seismic design forces by 2.5 times.

From capacity curve shown in Fig. 8, it can be seen that the linear behavior was observed up to $0.145 \%$ of lateral drifts and base shear corresponding to $32.8 \%$ of seismic weight. Plasticity developed in various RC members and infills of upper storey. The ultimate lateral strength of building was found to be $34 \%$ of seismic weight and corresponding drift was about $1.23 \%$. Failure of the RC frame building took place due to the flexure failure of the ground storey columns. Designing the soft storey column for 2.5 times the seismic design forces and increasing the shear strength of soft ground storey beams 2.5 times do not improve the lateral strength of frame significantly but the lateral deformability of the RC frame improves considerably (Kaushik et al. 2009). Yield lateral strength and ultimate strength of this type of frame building (SO3) was found to be increased by 2.47 and 2.09 times as compared to that of bare RC frame building respectively. Whereas yield and ultimate lateral strength of this type of building (SO3) was found to be 2.54 and 2.14 times more than that of open ground storey RC frame building respectively. Displacement ductility of this type of frame building was observed to be approximately $38 \%$ lower than that of bare frame building.

\subsection{Strengthening Option 4 (SO4): Providing Diagonal Bracing in Open Ground Storey}

In this study, the size and reinforcement details of bracing were kept similar to that of ground storey column, because strength of such bracings was generally very high and strength of the open ground story member was required to be increased by approximately 2.5 times as per IS 1893 . The considered building was strengthened by providing diagonal bracings at the ground story.

\subsubsection{Providing Diagonal Bracings in Alternate Bays (SO4a)}

First nonlinear behavior was observed at $0.041 \%$ drift and base shear corresponding to $52.47 \%$ of seismic weight as shown in Fig. 9. The ultimate lateral strength of building was observed $108.53 \%$ of seismic weight and corresponding drift was only $0.29 \%$, indicating very stiff system. Plastic hinges were found to develop almost in all the ground as well as upper storey members. However the failure of the building took place due to the failure of upper storey RC members. The infills at upper stories were worst affected due to their brittle character and high lateral stiffness. Considerable nonlinearity was also observed in the upper storey beams. Lateral yield and ultimate lateral strength of this type of frame building (SO4a) was increased by as much as 3.95 and 6.67 times as compared to that of bare RC frame building respectively. Whereas yield and ultimate lateral strength of this type of frame building (SO4a) was observed 4.06 and 6.85 times more than that of open ground storey RC frame building respectively. Displacement ductility of this type of frame building (SO4a) was observed approximately $48 \%$ lower than that of bare frame building.

\subsubsection{Providing Diagonal Bracings in All Bays (SO4b)}

Capacity curve for considered building strengthened using diagonal bracings in all bays (SO4b) is shown in fig. 10. The difference in the lateral strength of the building strengthens using option (SO4a) and option (SO4b) was almost negligible. However considerable variation in their ductility was observed. 
First inelastic activity was observed at $0.038 \%$ drift and lateral load corresponding to $58.22 \%$ of seismic weight. The failure of infill wall at upper storey was observed at ultimate lateral load of $115.87 \%$ of seismic weight and $0.33 \%$ of lateral drift, indicating very stiff structural system. However, the failure of the columns and diagonal bracing at the ground storey was not observed. Substantial increased in lateral strength as well as stiffness of RC braced frame building (SO4b) was observed as compared to other strengthening options. Yield and ultimate lateral strength of braced frame building (SO4b) was increased as much as 4.38 and 7.12 times as compared to that of bare RC frame building respectively. Whereas yield and ultimate lateral strength of this type of braced frame building (SO4b) was found to be 4.51 and 7.31 times higher than that of open ground storey RC frame building respectively. Displacement ductility of this type of frame building was observed to be approximately $35 \%$ lower than that of bare RC frame building.

\subsection{Strengthening Option 5 (SO5): Providing Lateral Buttresses in Open Ground Storey}

In this study for simplicity, the cross sectional dimension and reinforcement details of the buttress were kept similar to that of ground story columns. An axial force in the buttresses also depends on their inclination with reference to the frame. The highest lateral strength was observed when buttresses were provided at $60^{\circ}$ (Kaushik et al. 2009). Therefore in this study, RC lateral buttresses at an angle of $60^{\circ}$ with respected to the ground were provided for strengthening of RC frame building.

From fig. 11, it was observed that elastic behavior was observed up to $0.1 \%$ of lateral drifts and base shear corresponding to $45.36 \%$ of seismic weight. The ultimate lateral strength of the building was observed about $93.41 \%$ of seismic weight and corresponding drift was $2.59 \%$. Yield and ultimate lateral strength of this type of building (SO5) was increased as much as 3.42 and 5.74 times as compared to that of bare $\mathrm{RC}$ frame building respectively. Whereas yield and ultimate lateral strength of this type of frame building (SO5) was observed 3.51 and 5.89 times more than that of open ground storey RC frame building respectively. Plastic hinges were observed in several grounds as well as upper story columns, buttresses and at upper storey infills. The reduction the lateral strength of the building was observed due to the failure of infills, beam and column at upper stories. Although most of the plastic hinges are observed at ground storey members during early stage, no failure of ground storey columns and buttresses took place. Ductility of this type of strengthen building (SO5) was observed 1.05 and 1.47 times higher than that of bare RC frame and open ground storey building respectively.

\subsection{Comparisons of Lateral Strength, Deformability and Failure Pattern}

The lateral strength and deformation characteristics of considered asymmetric RC frame building strengthened using various options were evaluated using nonlinear static analysis and shown in Table 4 .

Yield lateral strength of the building strengthen as per SO4b (with diagonal braces in all bays) was observed maximum as compared to the other strengthening options. The yield lateral strength of RC frame building (SO4b) was observed 1.25 to 1.8 times higher than that of RC frame building strengthened using SO1, SO2, SO3, SO4a and SO5 respectively. Yield lateral strength of building (SO4b) was found to be 4.38 and 4.51 times higher than that of bare RC frame and open ground storey building respectively. Whereas ultimate lateral strength of building with SO4b was observed 7.12 and 7.31 times higher than that of bare RC frame and open ground storey building respectively. Ultimate lateral strength of braced frame building (SO4b) was observed the highest among all considered strengthening options. The ultimate lateral strength of the braced RC frame building (SO4b) was observed approximately 1.15, 3.1, 3.4, and 1.2 times higher than that observed in strengthening option SO1, SO2, SO3, and SO5 respectively. Yield lateral strength of building with SO5 was observed 3.42 and 3.51 times higher than that of bare RC frame and open ground storey building respectively. Whereas ultimate lateral strength of building with SO5 was observed 5.74 and 5.89 times higher than that of bare RC frame building and open ground storey building respectively.

The yield displacement of building strengthen using SO4b was merely about 33\% of that observed in building with SO1. Yield lateral strength of RC frame buildings strengthens using SO2 and SO3 were found about 55 to $70 \%$ of that observed in building with SO1. Yield lateral roof displacement of RC frame buildings strengthened as per SO2 and SO3 was found to be 1.15 and 1.42 times higher than that of SO1. The yield lateral displacement of frame strengthened as per SO5 was found to be about 2.5 
times higher than that of RC frame strengthened with SO4a and SO4b. The displacement ductility of building strengthened using option SO1, SO2, SO3, SO4a, SO4b was observed 49\%, 12\%, 13.3\%, 27.6\%, and $10.2 \%$ lower than that of open ground storey frame building. The RC frame building strengthened as per SO5 was subjected to highest ultimate lateral displacement, except the open ground storey frame and bare frame. At failure, lateral roof displacement of the frame strengthened as per SO5 (with lateral buttress) was found considerably higher than the other strengthening options. Ductility of frame strengthened using (SO5) was found to be 1.05 and 1.47 times higher than that of bare RC frame and open ground storey building respectively. Therefore, performance of RC frame used in SO5 in terms of ductility and lateral deformability was better than that shown by other strengthening options. The increased in the lateral strength of real life RC structure designs due to various considered strengthening options is expected to be even lower than what is computed here, because of various reasons, such as, torsional effects due to structural irregularity, lack of quality control and poor workmanship during the construction, not following the reinforcement detailing requirements exactly as per the codal guidelines, etc.

The behavior of bare RC frame building was found to be flexural and more ductile due to the absence of brittle masonry infills. The failure of study building having open ground-story was observed due to the flexure and shear failure of $\mathrm{RC}$ beams and columns. The lateral load carrying capacity of $\mathrm{RC}$ building having fully infilled frame (SO1) has been reduced significantly after the brittle failure of brick masonry infills at the ground as well as at upper stories. In case of building strengthened using SO2 (IS: 1893 method), the failure of RC frame occurred due to the flexural failure of the ground-story columns and the most of the hinges was found in the open ground-story columns on account of higher stiffness of these columns as compared to upper storey columns. The failure of building strengthened as per SO3 (only columns of soft-story designed for higher forces) took place due to flexural failure of ground-story columns at considerably lower lateral force and higher lateral deformation as compared to building strengthened using option SO2. In case of building strengthened by providing diagonal bracings (SO4) and lateral buttresses (SO5) at the open ground story, failure of RC frame took place due to flexural failure of the ground-story beams and/or upper-story columns, and axial compression failure of brick masonry infills at upper-story. However, the failure of ground storey columns, bracings, and lateral buttresses did not occur. It was observed that, seismic behavior of the frames strengthened by providing $\mathrm{RC}$ bracing and lateral buttress at the open ground story was significantly improved as compared to the strengthening options SO2 and SO3.

Table 4. Lateral strength and deformation characteristics

\begin{tabular}{c|c|c|c|c|c|c|c|c|c|c}
\hline $\begin{array}{c}\text { Strengthening } \\
\text { Option }\end{array}$ & $\begin{array}{c}\mathrm{F}_{\mathrm{y}} \\
(\mathrm{kN})\end{array}$ & $\delta_{\mathrm{y}}(\mathrm{m})$ & $\begin{array}{c}\mathrm{K}_{\mathrm{i}} \\
(\mathrm{kN} / \mathrm{m})\end{array}$ & $\begin{array}{c}\mathrm{F}_{\mathrm{u}} \\
(\mathrm{kN})\end{array}$ & $\delta_{\mathrm{u}}(\mathrm{m})$ & $\begin{array}{c}\mu_{\mathrm{d}}= \\
\delta_{\mathrm{u}} / \delta_{\mathrm{y}}\end{array}$ & $\mathrm{F}_{\mathrm{u}} / \mathrm{V}_{\mathrm{b}}$ & $\begin{array}{c}\mathrm{d}_{\mathrm{r}}= \\
100 \mathrm{x} \delta_{\mathrm{u}} / \mathrm{H} \\
(\%)\end{array}$ & $\begin{array}{c}\% \text { increase in } \mathrm{F}_{\mathrm{y}} \\
\text { as compared to } \\
\text { bare frame }\end{array}$ & $\begin{array}{c}\text { increase in } \mathrm{F}_{\mathrm{u}} \\
\text { as compared to } \\
\text { bare frame }\end{array}$ \\
\hline Bare frame & 1708 & 0.050 & 34373 & 2093 & 0.682 & 13.7 & 2.7 & 4.94 & 0.0 & 0.0 \\
\hline $\begin{array}{c}\text { Open ground } \\
\text { storey }\end{array}$ & 1661 & 0.045 & 36891 & 2039 & 0.439 & 9.8 & 2.6 & 3.2 & -2.8 & -2.6 \\
\hline SO1 & 6965 & 0.017 & 420480 & 12828 & 0.082 & 5.0 & 16.6 & 0.59 & 307.8 & 512.9 \\
\hline SO2 & 4717 & 0.019 & 244068 & 4800 & 0.166 & 8.6 & 6.2 & 1.20 & 176.2 & 129.3 \\
\hline SO3 & 4219 & 0.020 & 210888 & 4373 & 0.170 & 8.5 & 5.7 & 1.23 & 147.0 & 108.9 \\
\hline SO4a & 6749 & 0.006 & 1192492 & 13959 & 0.040 & 7.1 & 18.1 & 0.29 & 295.1 & 566.9 \\
\hline SO4b & 7489 & 0.005 & 1427633 & 14904 & 0.046 & 8.8 & 19.3 & 0.33 & 338.5 & 612.1 \\
\hline SO5 & 5835 & 0.025 & 234817 & 12015 & 0.357 & 14.4 & 15.6 & 2.59 & 241.6 & 474.1 \\
\hline
\end{tabular}

Note: $\mathrm{V}_{\mathrm{b}}=772 \mathrm{kN}, \mathrm{H}=13.8 \mathrm{~m} ; \mathrm{F}_{\mathrm{y}}=$ strength corresponding to first yielding; $\delta_{\mathrm{y}}=$ lateral roof displacement corresponding to $\mathrm{F}_{\mathrm{y}} ; \mathrm{K}_{\mathrm{i}}=$ initial stiffness; $\mathrm{F}_{\mathrm{u}}=$ ultimate lateral strength; $\delta_{\mathrm{u}}=$ lateral roof displacement corresponding to $\mathrm{F}_{\mathrm{u}}$ or point at which significant strength degradation has started; $\mu_{\mathrm{d}}=$ displacement ductility; $\mathrm{d}_{\mathrm{r}}$ $=\%$ drift corresponding to $\delta_{u}$. 


\section{Conclusions}

In this study, the assessment of some strengthening options in improving the performance of typical open ground-story asymmetric RC frame building in terms of lateral strength and ductility was carried out using nonlinear static pushover analyses. This study may be useful to decide the most effective strengthening option for asymmetric RC frame buildings by the design engineer. The significant outcomes of the present study are summarized as follows:

1. Large increase in stiffness as well as in lateral strength of considered RC frame building was observed when it strengthened using fully brick-infills (SO1). However sudden decline in lateral strength was observed after the failure of ground story brick-infills at comparatively lower lateral drift indicating its brittle behavior and lower ductility of the fully infill frame system.

2. The strengthening option suggested by IS:1893, designing the beams and columns of softstorey for higher forces (SO2) was found to increase the lateral strength of the RC frame. However, it was observed ineffective in improving the lateral deformability/ductility of $\mathrm{RC}$ frame building. Yield and ultimate lateral strength of this type of building (SO2) was found to be 2.76 and 2.29 times more than that of bare RC frame building respectively.

3. In case of building strengthened using SO3 (only soft-story columns designed for design forces), nominal decreased in the lateral strength and nominal increased in the lateral deformability was observed as compared to SO2.

4. In case of frame strengthened using diagonal braces at open ground storey (SO4), significant increase in stiffness and lateral strength of the buildings was observed, indicating the most efficient strengthening option. However sudden decreased in lateral strength was observed after the failure of masonry infills at upper storey. The ductility of this type of strengthened building was found to be noticeably lower than that of the frames strengthened according to SO5. Yield strength of frame (SO4b) was observed 4.38 and 4.51 times higher than that of bare $\mathrm{RC}$ frame and open ground storey building respectively. Whereas ultimate strength of this type of frame (SO4b) was observed 7.12 and 7.31 times higher than that of bare RC frame and open ground storey building respectively.

5. Provisions of lateral buttresses (SO5) at the open ground story significantly improve the lateral strength as well as ductility/deformability of frames. Ductility of frame strengthened using (SO5) was found to be 1.05 and 1.47 times higher than that of bare $\mathrm{RC}$ frame and open ground storey building respectively.

\section{References}

1. IS 1893, "Indian Standard criteria for earthquake resistant design of structures. Part 1: General provisions and buildings," Bureau of Indian Standards, New Delhi, India, 1984.

2. IS 1893, "Indian Standard criteria for earthquake resistant design of structures. Part 1: General provisions and buildings," Bureau of Indian Standards, New Delhi, India, 2002.

3. EN1998-1, "Design of structures for earthquake resistance-Part 1: General rules, seismic actions and rules for buildings," European Committee of Standardization, Eurocode 8, Brussels, Belgium. 2004.

4. IBC, "International Building Code," International Code Council, 2003.

5. Antonopoulos, T.A., Anagnostopoulos, S.A., "Optimum partial strengthening for improved seismic performance of old reinforced concrete buildings with open ground story," Advances in Performance-Based Earthquake Engineering, Geotechnical, Geo-logical, and Earthquake Engineering, M.N. Fardis (ed.), Springer, 13, pp. 395-404, 2010.

6. Jain S.K., Lettis. W. R., Murty C.V.R., and Bardet, J.P., ed., "Bhuj, India Earthquake of January 26, 2001reconnnaissance report," Earthquake Spectra, 18(S1), pp. 149-185, 2002.

7. Dolšek, M., Fajfar, P., "Soft storey effects in uniformly infilled reinforced concrete frames," Journal of Earthquake Eng., vol. 5(1), pp. 1-12, 2001. 
8. Tamboli Kruti, Amin J.A. (2015), "Evaluation of response reduction factor and ductility factor of RC braced frame," Journal of Materials and Engineering Structures, vol. 2, pp. 120-129, 2015.

9. Kaushik H. B., Rai D. C., Jain S. K.., "Effectiveness of some strengthening options for masonry-infilled RC frames with open first story," Journal of Structural Engineering, ASCE, 135 (8), pp. 925-937, 2009.

10.Das, S., Nau, J. M., "Seismic design aspects of vertically irregular reinforced concrete buildings." Earthquake Spectra, vol. 19(3), pp. 455-477, 2003.

11.Fardis, M. N., Negro, P., Bousias, S. N., and Colombo, A., "Seismic design of open-storey infilled RC buildings." J. Earthquake Eng., vol. 3(2), pp. 173-197, 1999.

12.Selvakoodalingam, B., Perumal Pillai, E. B., and Govindan, P., "Strengthening of RC infilled frame with opening," Concrete Int., vol. 21(11), pp. 37-42, 1999.

13.Negro, P., Colombo, A., "Irregularities induced by nonstructural masonry panels in framed buildings," Engineering Structure, vol. 19(7), pp. 576-585, 1997.

14.Structural Analysis Program (SAP2000) "Advanced, static and dynamic finite element analysis of structures," Computers and Structures Inc., Berkeley, Calif, 2010.

15.S 456. "Plain and Reinforced Concrete - Code of Practice," Bureau of Indian Standards New Delhi, India, 2000.

16.FEMA 356, "Prestandard and commentary for the rehabilitation of buildings," Federal Emergency Management Agency, Washington, D.C., 2000.

17.Park, R., Paulay, T., "Reinforced concrete structures," Wiley, New York, 1975.

18.Stafford- smith and Carter, C., "A method of analysis of infilled frames," proc. Of Institute of Civil Engineering (UK), vol. 44, pp. 31-48, 1969.

19.SII 413, "Design provisions for earthquake resistance of structures", Standards Institution of Israel Tel-Aviv, Israel, 1995. 